\title{
Cerebral blood flow during cardiopulmonary bypass in man: effect of arterial filtration
}

\author{
LEIF HENRIKSEN, ERIK HJELMS \\ From the Departments of Neurology and Thoracic Surgery, State University Hospital, Copenhagen, Denmark
}

ABSTRACT Cerebral blood flow was recorded in 39 patients undergoing cardiac surgery by intra- $\stackrel{\perp}{\oplus}$ arterial injection of xenon 133. There were three subgroups of patients: 10 patients had a 20 micron ir arterial filter (Johnson) and 11 a 40 micron filter (Pall), and 18 had no arterial filtration. All patients $\mathscr{\infty}_{\circ}$ had a 40 micron (Pall) filter in the coronary suction line. Significant changes in cerebral blood flow 0

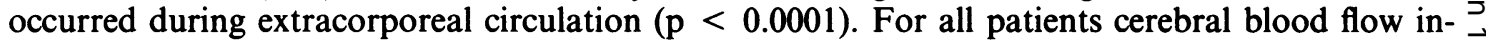
creased from a resting prebypass level of 30 to 46 and $57 \mathrm{ml} / 100 \mathrm{~g}$ a minute during initial and stable $z$ hypothermic extracorporeal circulation respectively. Both measurements were obtained at $26^{\circ} \mathrm{C}$ and $\stackrel{\mathscr{N}}{\sim}$ the recordings were made on average 12 and 55 minutes after the extracorporeal circulation was $\vec{\bullet}$ started. During rewarming cerebral blood flow increased to $64,53,41$, and $36 \mathrm{ml} / \mathrm{g}$ a minute at $31^{\circ}$, \% $33^{\circ}, 35^{\circ}$, and $37^{\circ} \mathrm{C}$ respectively, and when measured four and 16 minutes on average after bypass it 0 was 44 and $41 \mathrm{ml} / 100 \mathrm{~g}$ a minute. This general brain hyperperfusion was noticed in all patients with a high enough mean blood pressure to produce hyperaemia. Interposing 20 and 40 micron arterial $\frac{\partial}{0}$ filters reduced cerebral blood flow but did not prevent this hyperaemia. The cerebral autoregulation, $\stackrel{0}{\circ}$ which maintains a constant cerebral blood flow within wide limits of perfusion pressures, was not $\stackrel{\varnothing}{\varnothing}$ affected by arterial filtration. The lower limit of blood pressure at which a further reduction in blood $\overrightarrow{0}$ pressure was followed by a reduction in cerebral blood flow was around $60 \mathrm{~mm} \mathrm{Hg}$ in all three $\frac{3}{3}$ groups.

Currently postoperative mortality is of little use as a measure of the quality of cardiac surgery, as mortality rates are generally low, despite strikingly different perfusion techniques. A new index of the quality of surgery is emerging, based on psychometric analysis of the extent to which complex mental functioning is preserved in the early postoperative period, combined with more quantitative methods, such as analysis of spinal fluid intracellular markers ${ }^{1-3}$ and measurements of cerebral blood flow during and after cardiac surgery. ${ }^{4-8}$

In our earlier studies of cerebral blood flow during cardiac surgery we found a consistent hyperperfusion of the brain during cardiopulmonary bypass ${ }^{6-8}$ and a diffusely reduced regional cerebral blood flow after surgery, ${ }^{5}$ the most reasonable explanation being a

Address for reprint requests: Dr Leif Henriksen, Department of Neurology, Rigshospitalet, Blegdamsvej 9, DK-2100 Copenhagen, Denmark.

Accepted 13 November 1985 diffuse microvascular blockage of microembolic origin.

Filtration of the blood returned from the coronary suction line has become widely accepted, but the beneficial effect of arterial line filters is still ques-O tioned. The introduction of refined techniques for detecting microemboli present in the arterial line and ins the carotid arteries have suggested that the incidence of potentially hazardous microemboli during conventional cardiopulmonary bypass is much greater ${ }_{\sigma}$ than previously realised. Since the size of microemboli that would be safe cannot be defined, it seems reasonable to reduce the quantity as much as possible.

The present study was designed to determine whether arterial filtration could prevent the abnormale brain hyperperfusion usually noted in our patientso during bypass.

\section{Methods}

The results and their interpretation are based on aQ study of 39 unselected adult patients undergoing open 
Table 1 General and peroperative data (means (SE) [range]) on the patients having arterial filtration and the control patients with no filter

\begin{tabular}{|c|c|c|c|}
\hline & \multicolumn{2}{|l|}{ Filter groups } & \multirow[t]{2}{*}{ Controls } \\
\hline & $20 \mu \mathrm{m}$ filter & $40 \mu \mathrm{m}$ filter & \\
\hline $\begin{array}{l}\text { Number of patients } \\
\text { Age (y) } \\
\text { Perfusion time (min) } \\
\text { Aortic cross clamping (min) } \\
\text { Duration of hypotension during bypass (min) }\end{array}$ & $\begin{array}{l}10 \\
53.2(2.6)[40-65] \\
146(12)[107-209] \\
83(8)[46-130]\end{array}$ & $\begin{array}{l}11 \\
49.5(4.5)[27-69] \\
95(15)[60-235] \\
65(12)[30-171]\end{array}$ & $\begin{array}{l}18 \\
56.4(2.4)[40-72] \\
119(10)[72-205] \\
73(7)[22-142]\end{array}$ \\
\hline $\begin{array}{l}<40 \mathrm{~mm} \mathrm{Hg} \\
<50 \mathrm{~mm} \mathrm{Hg}\end{array}$ & $\begin{array}{r}4(2)[0-15] \\
22(6)[0-65]\end{array}$ & $\begin{array}{r}9(3)[0-25] \\
26(4)[10-50]\end{array}$ & $\begin{array}{r}8(2)[0-38] \\
29(4)[0-77]\end{array}$ \\
\hline $\begin{array}{l}\text { Preoperative mean arterial blood } \\
\text { pressure }(\mathrm{mm} \mathrm{Hg}) \\
\text { Haemolysis at end of bypass }(\mu \mathrm{mol} / \mathrm{l})\end{array}$ & $\begin{array}{l}103(7)[81-135] \\
\text { Not measured }\end{array}$ & $\begin{array}{l}94(5)[67-123] \\
11(2)[2-28]\end{array}$ & $\begin{array}{l}97(3)[73-120] \\
16(3)[2-49]\end{array}$ \\
\hline
\end{tabular}

heart surgery. All patients had a $\mathbf{4 0}$ micron filter (Pall) in the cardiotomy suction line. In 21 patients arterial filtration was used: a 20 micron (Johnson) filter in 10 patients and a $\mathbf{4 0}$ micron (Pall) filter in 11 patients; 18 patients with no arterial filtration served as controls. A total of 670 measurements of cerebral blood flow with associated variables were obtained: 201 measurements in the group with a 20 micron filter, 180 in the group with a 40 micron filter, and 289 in the control group. The experimental protocol was approved by the chairman of the department of cardiothoracic surgery. Informed consent for the study was obtained from all patients before the study.

\section{STUDY GROUP AND MEASUREMENTS}

Table 1 summarises the general data and peroperative information for all patients. There were 21 men and 18 women with a mean age of 54 years. The operative procedures were: aortic valve replacement in 17 , mi- tral valve replacement in 11 , coronary artery bypass grafting in 10 , and mitral valve replacement with coronary artery bypass grafting in one patient. None of the patients had any history or clinical evidence of cerebral vascular disease.

A baseline measurement was obtained between sternotomy and extracorporeal circulation. The next two measurements were obtained during the initial and the stable phases of hyperthermic extracorporeal circulation, 12 and 55 minutes on average after its initiation. During the rewarming phase of extracorporeal circulation measurements were obtained at $31^{\circ}, 33^{\circ}, 35^{\circ}$, and $37^{\circ} \mathrm{C}$. Final measurements were obtained twice after the end of the extracorporeal circulation, on average four and $\mathbf{1 6}$ minutes after it had finished.

\section{ANAESTHESIA}

The patients were premedicated with 5-10 $\mathrm{mg}$ of mor-

Table 2 Cerebral blood flow and associated measurements (mean (SE)) in 10 patients with a 20 micron arterial filter obtained before, during, and after extracorporeal circulation (ECC)

\begin{tabular}{|c|c|c|c|c|c|c|c|c|c|c|}
\hline \multirow[b]{3}{*}{ Flow: } & \multirow{3}{*}{$\begin{array}{l}\text { Before } \\
\text { ECC }\end{array}$} & \multicolumn{6}{|c|}{ During ECC } & \multirow{2}{*}{\multicolumn{2}{|c|}{ After ECC }} & \multirow{3}{*}{$\begin{array}{l}\text { Kruskal-Wallis } \\
\text { analysis of } \\
\text { variance }(p)\end{array}$} \\
\hline & & \multicolumn{2}{|c|}{ Hypothermia } & \multicolumn{4}{|c|}{ Rewarming } & & & \\
\hline & & 1 & 2 & $I$ & 2 & 3 & 4 & 1 & 2 & \\
\hline \multicolumn{11}{|l|}{ Cerebral blood flow* } \\
\hline$(\mathrm{ml} / 100 \mathrm{~g}$ per min) & $(1.5)$ & $\begin{array}{l}(3.7) \\
55\end{array}$ & $(2.8)$ & $(6.9)$ & $\begin{array}{l}(6.0) \\
70\end{array}$ & $\begin{array}{l}(5.5) \\
65\end{array}$ & $\begin{array}{l}(2.5) \\
57\end{array}$ & $\begin{array}{l}(6.6) \\
60\end{array}$ & $\begin{array}{l}(6.8) \\
58\end{array}$ & $<0.0001$ \\
\hline $\begin{array}{l}\text { Mean artenal pressure } \\
\text { (mm Hg) }\end{array}$ & $\begin{array}{l}70 \\
(2.1)\end{array}$ & $\begin{array}{l}55 \\
(2.9)\end{array}$ & $\begin{array}{l}61 \\
(1.4)\end{array}$ & $\begin{array}{l}72 \\
(3.3)\end{array}$ & (2.9) & (2.9) & (1.6) & (3.8) & (2.3) & \\
\hline Carbon dioxide tension & $\begin{array}{l}39.7 \\
(1.1)\end{array}$ & $\begin{array}{l}33.5 \\
(0.8)\end{array}$ & $\begin{array}{l}42.1 \\
(0.8)\end{array}$ & $\begin{array}{l}52.6 \\
(2.2)\end{array}$ & $\begin{array}{l}53.7 \\
(4.0)\end{array}$ & $\begin{array}{l}56.7 \\
(3.5)\end{array}$ & $\begin{array}{l}58.1 \\
(2.2)\end{array}$ & $\begin{array}{l}53.2 \\
(8.3)\end{array}$ & $\begin{array}{l}62.1 \\
(7.0)\end{array}$ & $<0.0001$ \\
\hline Packed cell volume & $\begin{array}{l}0.37 \\
(0.01)\end{array}$ & $\begin{array}{l}0.24 \\
(0.01)\end{array}$ & $\begin{array}{l}0.24 \\
(0.01)\end{array}$ & $\begin{array}{l}0.25 \\
(0.02)\end{array}$ & $\begin{array}{l}0.27 \\
(0.02)\end{array}$ & $\begin{array}{l}0.25 \\
(0.02)\end{array}$ & $\begin{array}{l}0.23 \\
(0.01)\end{array}$ & $\begin{array}{l}0.28 \\
(0.01)\end{array}$ & $\begin{array}{l}0.25 \\
(0.01)\end{array}$ & $<0.0001$ \\
\hline Temperature $\left({ }^{\circ} \mathrm{C}\right) \dagger$ & $\begin{array}{l}35.8 \\
(0.1)\end{array}$ & $\begin{array}{l}24.0 \\
(0.7)\end{array}$ & $\begin{array}{l}24.2 \\
(0.3)\end{array}$ & $\begin{array}{l}28.8 \\
(0.7)\end{array}$ & $\begin{array}{l}33.5 \\
(0.2)\end{array}$ & $\begin{array}{l}35.3 \\
(0.2)\end{array}$ & $\begin{array}{l}37.0 \\
(0.2)\end{array}$ & $\begin{array}{l}36.5 \\
(0.3)\end{array}$ & $\begin{array}{l}36.4 \\
(0.3)\end{array}$ & $<0.0001$ \\
\hline $\begin{array}{l}\text { Measurement time before, } \\
\text { during, and after ECC } \\
\text { (min) }\end{array}$ & $\begin{array}{r}-13 \\
(1.7)\end{array}$ & $\begin{array}{l}14 \\
(1.4)\end{array}$ & $\begin{array}{l}53 \\
(2.5)\end{array}$ & $\begin{array}{l}80 \\
(6.6)\end{array}$ & $\begin{array}{l}85 \\
(4.7)\end{array}$ & $\begin{array}{l}98 \\
(5.6)\end{array}$ & $\begin{array}{l}131 \\
(5.7)\end{array}$ & $\begin{array}{l}4 \\
(0.7)\end{array}$ & $\begin{array}{l}17 \\
(2.2)\end{array}$ & \\
\hline
\end{tabular}

*Cerebral blood flow has been corrected to a carbon dioxide tension of $40 \mathrm{~mm} \mathrm{Hg}, 1 \mathrm{~mm} \mathrm{Hg}$ giving about a $3 \%$ change in cerebral blood flow. ${ }^{10}$

tSee p 390 for details.

Conversion: Traditional to SI units-Carbon dioxide tension: $1 \mathrm{~mm} \mathrm{Hg} \approx 0.133 \mathrm{kPa}$. 
Table 3 Cerebral blood flow and associated measurements (mean (SE)) in 11 patients with a 40 micron arterial filter obtained before, during, and after extracorporeal circulation (ECC)

\begin{tabular}{|c|c|c|c|c|c|c|c|c|c|c|}
\hline \multirow[b]{3}{*}{ Flow: } & \multirow{3}{*}{$\begin{array}{l}\text { Before } \\
\text { ECC }\end{array}$} & \multicolumn{6}{|c|}{ During $E C C$} & \multirow{2}{*}{\multicolumn{2}{|c|}{ After ECC }} & \multirow{3}{*}{$\begin{array}{l}\text { Kruskal-Wallis } \\
\text { analysis of } \\
\text { variance }(p)\end{array}$} \\
\hline & & \multicolumn{2}{|c|}{ Hypothermia } & \multicolumn{4}{|c|}{ Rewarming } & & & \\
\hline & & 1 & 2 & 1 & 2 & 3 & 4 & 1 & 2 & \\
\hline \multicolumn{11}{|l|}{ Cerebral blood flow* } \\
\hline corrected for $\mathrm{PCO}_{2}$ & 31 & 46 & & 56 & 46 & 36 & 41 & 40 & 37 & $<0.0001$ \\
\hline $\begin{array}{l}(\mathrm{ml} / 100 \mathrm{~g} \text { per } \mathrm{min}) \\
\text { Mean arterial pressure }\end{array}$ & $\begin{array}{l}(2.1) \\
75\end{array}$ & $\begin{array}{l}(4.0) \\
47\end{array}$ & $\begin{array}{l}(5.2) \\
53\end{array}$ & $\begin{array}{l}(6.8) \\
61\end{array}$ & & & $\begin{array}{l}(4.7) \\
52\end{array}$ & $\begin{array}{l}(3.3) \\
63\end{array}$ & $(6.4)$ & $<0.0001$ \\
\hline $\begin{array}{l}(\mathrm{mm} \mathrm{Hg}) \\
\text { Carbon dioxide tension }\end{array}$ & $\begin{array}{l}(2.8) \\
35.9\end{array}$ & $\begin{array}{l}(1.9) \\
34.0\end{array}$ & $\begin{array}{l}(1.9) \\
42.1\end{array}$ & $\begin{array}{l}(3.4) \\
48.8\end{array}$ & $\begin{array}{l}(4.5) \\
50.5\end{array}$ & $\begin{array}{l}(4.9) \\
53.4\end{array}$ & $\begin{array}{l}(2.7) \\
51.9\end{array}$ & $\begin{array}{l}(4.1) \\
46.5\end{array}$ & $\begin{array}{l}(2.9) \\
48.5\end{array}$ & $<0.0001$ \\
\hline$(\mathrm{mm} \mathrm{Hg})$ & $(0.8)$ & $(0.8)$ & (1.0) & $(1.0)$ & (1.4) & (1.1) & (1.8) & $(1.0)$ & (1.3) & \\
\hline Packed cell volume & $\begin{array}{l}0.39 \\
(0.01)\end{array}$ & $\begin{array}{l}0.24 \\
(0.01)\end{array}$ & $\begin{array}{l}0.24 \\
(0.01)\end{array}$ & $\begin{array}{l}0.25 \\
(0.01)\end{array}$ & $\begin{array}{l}0.25 \\
(0.01)\end{array}$ & $\begin{array}{l}0.26 \\
(0.01)\end{array}$ & $\begin{array}{l}0.26 \\
(0.01)\end{array}$ & $\begin{array}{l}0.27 \\
(0.01)\end{array}$ & $\begin{array}{l}0.27 \\
(0.01)\end{array}$ & $<0.0001$ \\
\hline Temperature $\left({ }^{\circ} \mathrm{C}\right) \dagger$ & 36.5 & 26.9 & 26.5 & 30.1 & 32.7 & 35.0 & 36.6 & 36.2 & 35.8 & $<0.0001$ \\
\hline \multirow{2}{*}{$\begin{array}{l}\text { Measurement time before, } \\
\text { during, and after ECC } \\
\text { (min) }\end{array}$} & & & & & & & & & & \\
\hline & $\begin{array}{l}-7 \\
(1.0)\end{array}$ & $\stackrel{9}{(0.9)}$ & $\begin{array}{l}54 \\
(7.0)\end{array}$ & $\begin{array}{l}66 \\
(15.3)\end{array}$ & $\begin{array}{l}70 \\
(12.8)\end{array}$ & $\begin{array}{l}86 \\
(15.6)\end{array}$ & $\begin{array}{l}87 \\
(11.1)\end{array}$ & $\begin{array}{l}4 \\
(0.6)\end{array}$ & $\begin{array}{l}13 \\
(1.5)\end{array}$ & \\
\hline
\end{tabular}

- See first footnote to table 2.

tSee p 390 for details.

Conversion: Traditional to SI units-Carbon dioxide tension: $1 \mathrm{~mm} \mathrm{Hg} \approx 0.133 \mathrm{kPa}$.

phine or $10-15 \mathrm{mg}$ of diazepam plus scopolamine $0.2-0.4 \mathrm{mg}$ given intramuscularly. General anaesthesia was started with thiopental $2-4 \mathrm{mg} / \mathrm{kg}$ intravenously. Pancuronium and suxamethonium were given intravenously for muscle relaxation. The patients received $1.5 \%$ enflurane in pure oxygen as volatile anaesthetic which was stopped at the time of bypass. During the extracorporeal circulation anaesthesia was maintained with fentanyl $5-10 \mu \mathrm{g} / 10 \mathrm{~kg}$ intravenously and with $0.3-0.6 \mathrm{mg}$ of scopolamine intravenously. Rewarming was usually facilitated with chlorpromazine at a dose of up to $0.5 \mathrm{mg} / \mathrm{kg}$.
CARDIOPULMONARY BYPASS

The extracorporeal technique consisted of a Rygg Kyvsgaard heart-lung machine with a bubble oxygen? ator. A 40 micron filter (Pall) was used in the cardiotomy suction line in all patients. Arteria filtration was used in 21 patients: a 20 micron filte (Johnson) in 10 patients and a 40 micron filter (PalP in 11 patients. The filters were continuously bled int $\overline{0}$ the venous line with a flow rate of about $100 \mathrm{ml} / \mathrm{min}$. The priming was Ringer's lactate, 2.0-2.5 1. During extracorporeal circulation the extracorporeal flow rate was maintained at $1.8-2.41 / \mathrm{min}$ per $\mathrm{m}^{2}$. The ex

Table 4 Cerebral blood flow and associated measurements (mean (SE)) in 18 control patients without an arterial filter obtained before, during, and after extracorporeal circulation (ECC)

\begin{tabular}{|c|c|c|c|c|c|c|c|c|c|c|}
\hline \multirow[b]{3}{*}{ Flow: } & \multirow{3}{*}{$\begin{array}{l}\text { Before } \\
\text { ECC }\end{array}$} & \multicolumn{6}{|c|}{ During $E C C$} & \multirow{2}{*}{\multicolumn{2}{|c|}{ After ECC }} & \multirow{3}{*}{$\begin{array}{l}\text { Kruskal-Walli } \\
\text { analysis of } \\
\text { variance }(p)\end{array}$} \\
\hline & & \multicolumn{2}{|c|}{ Hypothermia } & \multicolumn{4}{|c|}{ Rewarming } & & & \\
\hline & & 1 & 2 & 1 & 2 & 3 & 4 & 1 & 2 & \\
\hline $\begin{array}{l}\text { Cerebral blood flow* } \\
\text { corrected for } \mathrm{PCO}_{2} \\
\text { (ml/100 per min) } \\
\text { Mean arterial pressure } \\
\text { (mm } \mathrm{Hg}) \\
\text { Carbon dioxide tension } \\
(\mathrm{mm} \mathrm{Hg}) \\
\text { Packed cell volume } \\
\text { Temperature }\left({ }^{\circ} \mathrm{C}\right) \dagger\end{array}$ & $\begin{array}{l}33 \\
(2.3) \\
77 \\
(2.6) \\
35.2 \\
(1.0) \\
0.37 \\
(0.01) \\
36.2 \\
(0.1)\end{array}$ & $\begin{array}{l}44 \\
(2.7) \\
49 \\
(2.4) \\
34.0 \\
(1.0) \\
0.25 \\
(0.01) \\
27.2 \\
(0.5)\end{array}$ & $\begin{array}{l}57 \\
(3.2) \\
58 \\
(1.9) \\
40.4 \\
(0.8) \\
0.25 \\
(0.01) \\
26.8 \\
(0.3)\end{array}$ & $\begin{array}{l}72 \\
(5.7) \\
65 \\
(3.5) \\
43.8 \\
(1.1) \\
0.24 \\
(0.01) \\
30.1 \\
(0.3)\end{array}$ & $\begin{array}{l}65 \\
(4.9) \\
62 \\
(2.6) \\
45.0 \\
(1.2) \\
0.25 \\
(0.01) \\
32.7 \\
(0.2)\end{array}$ & $\begin{array}{l}49 \\
(3.6) \\
57 \\
(2.2) \\
49.0 \\
(1.4) \\
0.25 \\
(0.01) \\
35.2 \\
(0.1)\end{array}$ & $\begin{array}{l}38 \\
(2.8) \\
51 \\
(1.9) \\
50.6 \\
(1.1) \\
0.25 \\
(0.01) \\
37.2 \\
(0.1)\end{array}$ & $\begin{array}{l}47 \\
(3.3) \\
63 \\
(2.8) \\
42.2 \\
(1.4) \\
0.25 \\
(0.01) \\
36.6 \\
(0.1)\end{array}$ & $\begin{array}{l}49 \\
(6.0) \\
67 \\
(3.2) \\
36.2 \\
(1.3) \\
0.27 \\
(0.01) \\
36.2 \\
(0.1)\end{array}$ & $\begin{array}{l}<0.0001 \\
<0.0001 \\
<0.0001 \\
<0.0001 \\
<0.0001\end{array}$ \\
\hline $\begin{array}{l}\text { Measurement time before, } \\
\text { during, and after ECC } \\
\text { (min) }\end{array}$ & $\begin{array}{l}-13 \\
(1.6)\end{array}$ & $\begin{array}{l}13 \\
(1.1)\end{array}$ & $\begin{array}{l}57 \\
(4.1)\end{array}$ & $\begin{array}{l}69 \\
(7.7)\end{array}$ & $\begin{array}{l}74 \\
(6.3)\end{array}$ & $\begin{array}{l}81 \\
(7.0)\end{array}$ & $\begin{array}{l}105 \\
(5.0)\end{array}$ & $\begin{array}{l}4 \\
(0.5)\end{array}$ & $\begin{array}{l}18 \\
\text { (1.9) }\end{array}$ & \\
\hline $\begin{array}{l}\text { *See first footnote to table } 2 \\
+ \text { See } \mathrm{p} 390 \text { for details. } \\
\text { Conversion: Traditional to } S\end{array}$ & its-Car & 年 & . & 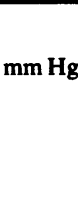 & ( & & & & & \\
\hline
\end{tabular}


CBF

uncorrected

(ml $/ 100 \mathrm{~g}$

per $\min$ )

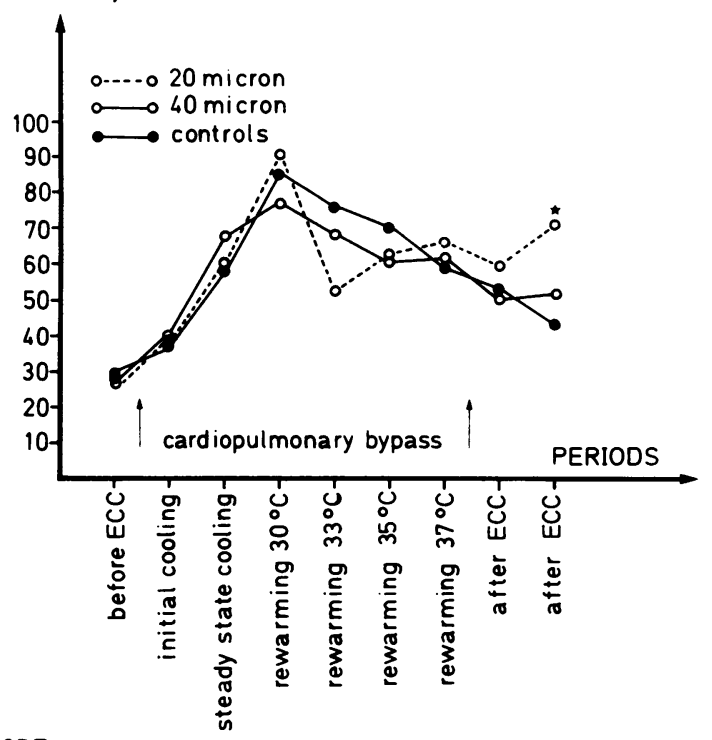

CBF

corrected

(ml / $100 \mathrm{~g}$

per min)

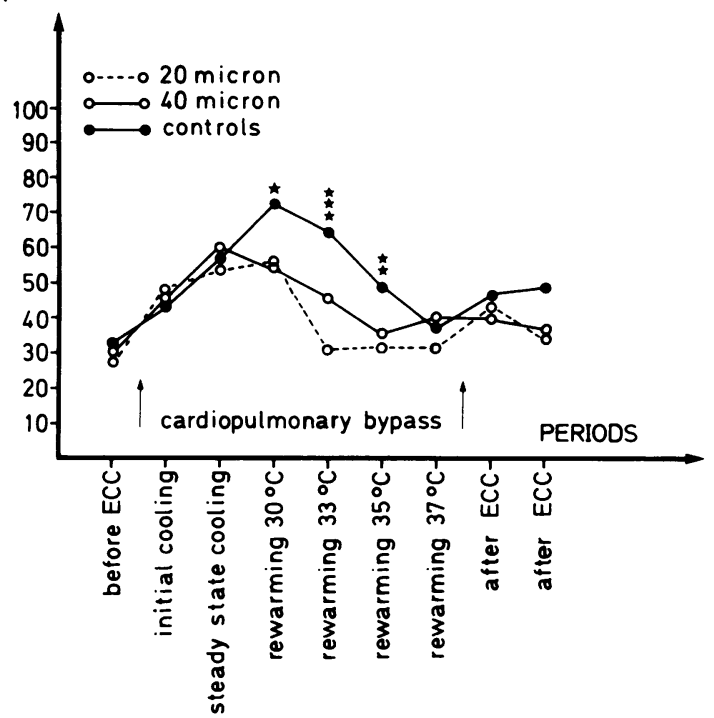

Fig 1 Cerebral blood flow (CBF) measured during nine periods of cardiac surgery: before bypass, twice during hypothermic bypass, four times during the rewarming procedure, and twice after bypass. (a) Uncorrected cerebral blood flow; (b) cerebral blood flow corrected to a carbon dioxide tension of $40 \mathrm{~mm} \mathrm{Hg}(5.3 \mathrm{kPa})$. Significance:

${ }^{* * *} p<0.002 ;{ }^{* *} p<0.01 ; p<0.05$. ECC-extracorporeal circulation. tracorporeal circulation was started with gradually increasing flow, full flow being established within the first minute. Bretschneider's or St Thomas' cardioplegic solution, at $4^{\circ} \mathrm{C}$, was infused into the aortic root just after aorta had been cross clamped. Cooling was induced until an oesophageal temperature of $28-30^{\circ} \mathrm{C}$ was reached and the temperature was kept at this level during the cardiac repair. Carbon dioxide was added to the oxygenator to give a concentration of $5 \%$ until steady state hypothermia had been reached, and then reduced to 3\%. During rewarming the temperature gradient between the oxygenator and the patient was not allowed to exceed $12^{\circ} \mathrm{C}$. Table 1 summarises data on the patients for the bypass period.

\section{CEREBRAL BLOOD FLOW}

Cerebral blood flow was measured with the xenon 133 intra-arterial injection method ${ }^{9} 10$ modified for studies in man during open heart surgery. ${ }^{6}$ This method allows rapid repetitive measurement of cerebral blood flow. ${ }^{133} \mathrm{Xe}$ was injected into the right common or the internal carotid artery and the clearance of ${ }^{133} \mathrm{Xe}$ was followed by a single $2.5 \mathrm{~cm} \mathrm{NaI}$ crystal positioned over the right parietal region. Cerebral blood flow (CBF) was calculated by the initial slope method, ${ }^{10}$ the formula being $C B F=-\lambda \cdot \ln 10 \cdot D_{0} \cdot 100$ $(\mathrm{ml} / 100 \mathrm{~g}$ per minute), where the blood-brain partition coefficient for grey matter, $\lambda$, is $0.87 \mathrm{ml} / \mathrm{g}$ and

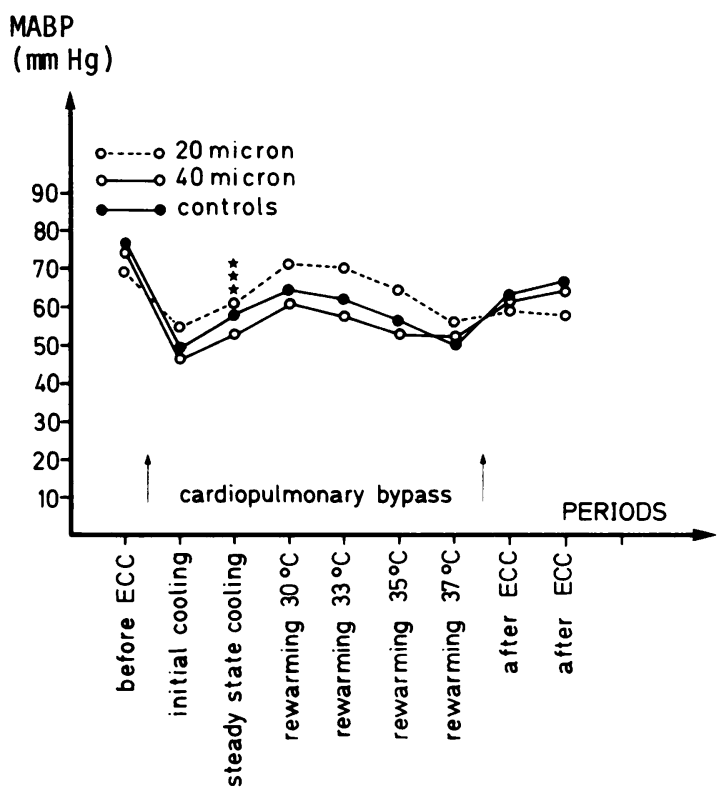

Fig 2 Mean arterial blood pressure (MABP) changes during the nine measurement periods of cardiac surgery in the three groups of patients. Significance: ${ }^{* * *} p<0.002$; ECC-extracorporeal circulation. 
$D_{0}$ is the initial slope (the first $10-40 \mathrm{~s}$ ) of a logarithmic recording of the clearance curve.

Mean arterial blood pressure, packed cell volume, carbon dioxide tension $\left(\mathrm{PCO}_{2}\right)$, oxygen tension $\left(\mathrm{Po}_{2}\right)$, and temperatures (oesophagus, rectum, arterial line) were measured each time cerebral blood flow was measured. The blood gases were measured at $37^{\circ} \mathrm{C}$ (ABL4 Radiometer, Copenhagen) and corrected to the relevant temperature.

\section{TEMPERATURE}

We have previously measured temperatures in the rectum, oesophagus, rhinopharynx, tympanic membrane, arterial line, and the bulb of the internal jugular vein. From these measurements, using the temperature in the bulb of the jugular vein as a reference we concluded that the best routine estimate of the brain temperature is the mean of the oesophagus and the arterial line temperatures. The second best choice is the oesophageal temperature. The temperature is not crucial in this study, however, and when temperature is mentioned it refers either to rectal temperature (before extracorporeal circulation), the mean of the arterial and the oesophageal temperatures (during the procedure), or oesophageal temperature (after extracorporeal circulation).

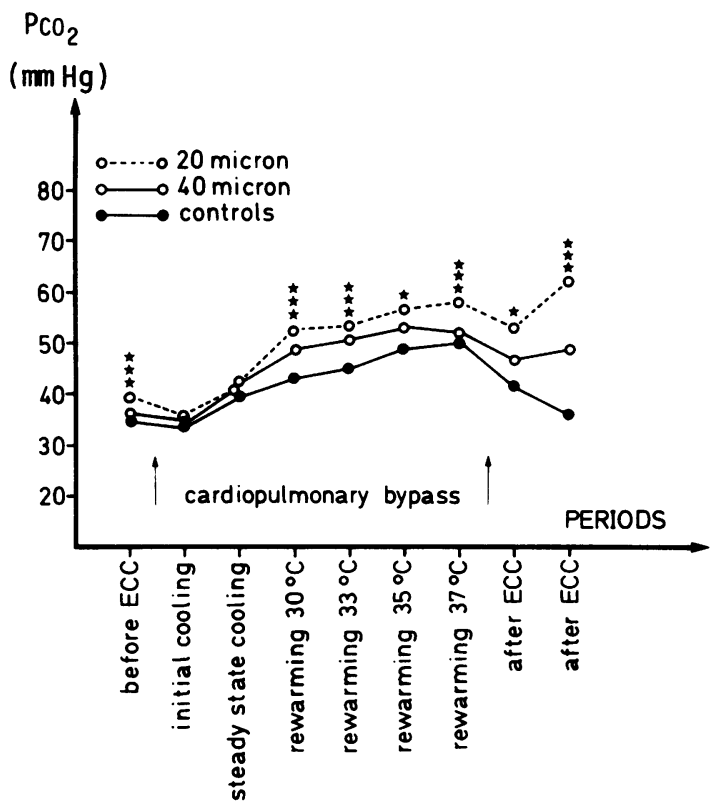

Fig 3 Plasma carbon dioxide tension $\left(\mathrm{PCO}_{2}\right)$ corrected to the actual temperature during the nine measurement periods of cardiac surgery in the three groups of patients.

Significance: ${ }^{* * *} p<0.0002 ;{ }^{*} p<0.05$.

ECC-extracorporeal circulation. Conversion: Traditional to $\mathrm{SI}$ units- $\mathrm{PCO}_{2}: 1 \mathrm{~mm} \mathrm{Hg} \approx 0.133 \mathrm{kPa}$.
STATISTICS

Owing to a skew distribution non-parametric statis- $\overrightarrow{\vec{F}}$ tics were preferred. ${ }^{11}$ Analysis of variance within and $\stackrel{\sim}{\stackrel{(}{+}}$ between the groups was performed with KruskalWallis rank test. The significance level was $p<0.05$.

\section{Results}

During extracorporeal circulation significant changes in cerebral blood flow occurred in all the patients studied $(\mathrm{p}<0.0001)$. Mean cerebral blood flow for $\vec{\omega}$ the whole group $(\mathrm{n}=39)$ increased from $30 \mathrm{ml} / 100 \mathrm{~g}$ o a minute before bypass to 46 and $57 \mathrm{ml} / 100 \mathrm{~g}$ a minute $\overrightarrow{\vec{x}}$ during the initial and stable hypothermic phases re- $\stackrel{x}{A}$ spectively. During the rewarming procedure cerebral $\vec{i}$ blood flow was $64,53,41$, and $36 \mathrm{ml} / 100 \mathrm{~g}$ a minute at $\dot{\omega}$ $31^{\circ}, 33^{\circ}, 35^{\circ}$, and $37^{\circ} \mathrm{C}$. Four and 16 minutes after $\stackrel{\circ}{\circ}$ extracorporeal circulation had ended cerebral blood $\mathrm{O}$ flow was 44 and $41 \mathrm{ml} / 100 \mathrm{~g}$ a minute. The corresponding values for the three subgroups are presented $>$ in tables 2-4 and figures 1-3.

Interposing arterial filters only slightly modified the hyperperfusion during extracorporeal circulation. Correcting cerebral blood flow for changes in $\mathrm{PCO}_{2}$ to a standard $\mathrm{PCO}_{2}$ of $40 \mathrm{~mm} \mathrm{Hg}(5.3 \mathrm{kPa})$ showed that the hyperaemia was to some extent prevented during the rewarming procedure at $30^{\circ}, 33^{\circ}$, and $35^{\circ} \mathrm{C}(\mathrm{p}<$ $0.05,<0.002$, and $<0.01$ respectively), the smallest filter pore size ( 20 micron) being most efficient (fig 1). The same trend towards a lower cerebral blood flow was noted when cerebral blood flow was not corrected for changes in $\mathrm{PCO}_{2}$ (fig $1 a$ ). When the 21 CBF

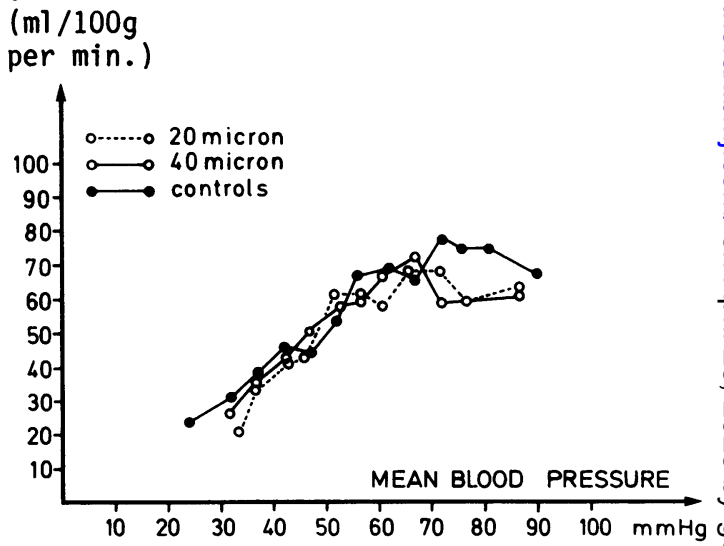

Fig 4 Cerebral autoregulation for cerebral blood flow $(C B F)$ and mean arterial blood pressure (MABP): measurements obtained during and after cardiac surgery in the three groups of patients. Only cerebral blood flow measurements obtained after bypass was started are included to avoid the abrupt change in packed cell volume at the start of bypass. 
$\mathrm{CBF}$

( $\mathrm{ml} / 100 \mathrm{~g}$

per $\min )$

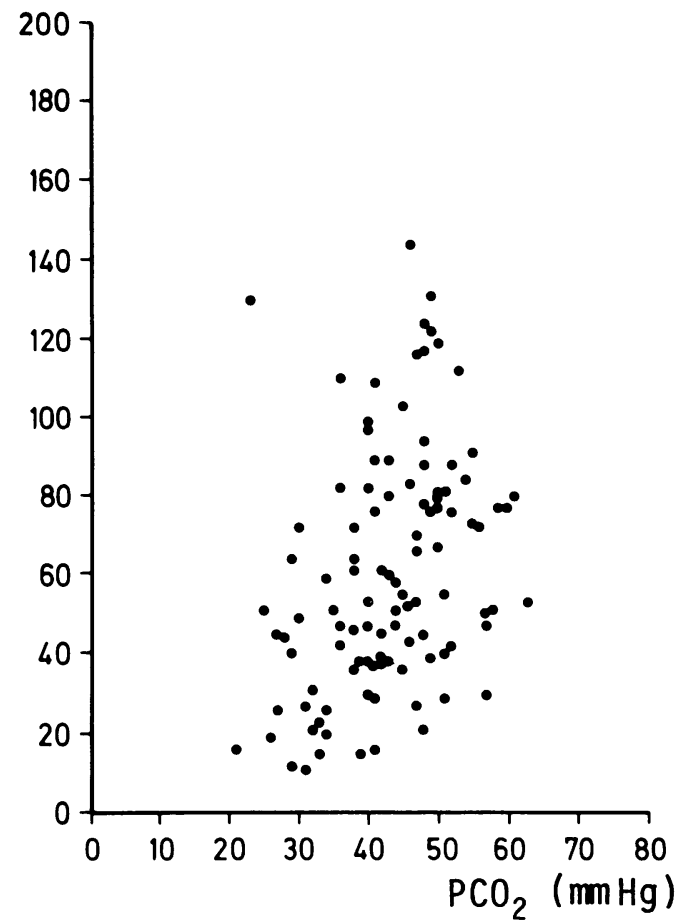

Fig 5 Plasma carbon dioxide tension $\left(\mathrm{PCO}_{2}\right)$ in relation to cerebral blood flow (CBF) before, during, and after cardiopulmonary bypass.

patients having 20 or 40 micron arterial filters were compared with the 18 controls during the rewarming period at $33^{\circ}$ and $35^{\circ} \mathrm{C}$, the cerebral blood flow was lowest in the patients with filters $(62$ and $73 \mathrm{ml} / 100 \mathrm{~g} \mathrm{a}$ minute; $p<0.05$ ). The total number of cerebral blood flow measurements with associated measurements during the period of bypass was 37 for both groups. The other measurements for the filter and the control group were: mean arterial blood pressure 60 and $60 \mathrm{~mm} \mathrm{Hg}(8 \mathrm{kPa}), \mathrm{PCO}_{2} 53.3$ and $47.1 \mathrm{~mm} \mathrm{Hg}(7.1$ and $6.3 \mathrm{kPa})$, packed cell volume 0.25 and 0.25 , and temperature $34.1^{\circ}$ and $34.0^{\circ} \mathrm{C}$. There is a notable difference in $\mathbf{P C O}_{2}$ between the groups (fig 3). Any correction will accentuate the difference in cerebral blood flow, being lowest in the patients with arterial filtration (fig $1 b$ ). The general trend, however, despite arterial filtration, was for all patients to show the same tendency towards hyperperfusion during extracorporeal circulation.

The cerebral autoregulation, reflecting the re- lationship between cerebral blood flow and mean arterial blood pressure during and after extracorporeal circulation was the same for all three groups (fig 4). Reducing mean arterial blood pressure below $55-60 \mathrm{~mm} \mathrm{Hg}$ was followed by a fall in cerebral blood flow, the lower limit of autoregulation being exceeded.

Carbon dioxide tension (fig 5) was an important determinant of cerebral blood flow $(p<0.001)$.

\section{Discussion}

Operations with extracorporeal circulation cause impairment of intellectual function. ${ }^{312-25}$ This probably reflects cerebral injuries that are mostly reversible, but signs of permanent injuries do occur. ${ }^{1-3526}$ The earlier and more extensively the patients have been tested, the higher has been the incidence and severity of the observed deficits. ${ }^{1213}$

Emboli from valve calcification and intracardiac air are commonly detected in the carotid artery when the left ventricle begins to eject, ${ }^{27}$ but exposure to extracorporeal circulation is probably the most important operative risk factor. Microembolisation, the duration of perfusion, hypotension during perfusion, and $\mathrm{PCO}_{2}$ also seem to be of aetiological importance in the postoperative encephalopathic syndrome that follows most cardiac operations. 51228

The potential dangers of extracorporeal circulation are important because of the increasing number of valve and coronary artery bypass operations. In the United States coronary bypass grafting is now as commonplace as hysterectomy and appendicectomy, ${ }^{29}$ so there is no room for complacency until the optimal bypass technique has been evolved.

\section{EMBOLI}

The general pattern of cerebral blood flow during operation was constant for all patients whether arterial filtration was used or not. The second measurement obtained during initial cooling (an average of 12 minutes after the onset of extracorporeal circulation) showed an increase in cerebral blood flow matching the haemodilution, but given the hypothermic state $\left(26^{\circ} \mathrm{C}\right)$ it was too high. The further increase during steady state hypothermia and the rewarming procedure was unexpected (fig 1). Although it is difficult to point to a single factor as the main cause of the peroperative brain hyperperfusion and the postoperative encephalopathic syndrome, cerebral microembolisation probably plays the leading part, the hyperaemia being a reaction to a prior diffuse hypoperfusion. ${ }^{56}$

Blood circulating through a pump oxygenator system during cardiopulmonary bypass carries many embolising particles, most of which originate from the 
coronary suction line ${ }^{30-32}$ Lipid and other aspirated material account for some of the particles detected in the cardiotomy return blood, but platelet aggregates probably constitute the major portion by volume of the particulate microemboli. ${ }^{32}$ Gaseous microemboli are probably also important in the pathogenesis of brain hyperperfusion. Inevitably saturated liquids degas and form gaseous microemboli when temperatures increase, owing to a reduced solubility. This aspect of extracorporeal circulation is particularly important at the onset of bypass, particularly if nitrous oxide has been continued until perfusion begins. ${ }^{33}$ Defoaming is never complete and the small bubbles are carried by liquid flow into the arterial line before they can rise to the surface of the arterial reservoir. The smaller diameter bubbles are more likely to be trapped because buoyancy is directly related to size. The capability of the arterial line filter to trap gas bubbles may be the main advantage of using the filter in that position. We had no Doppler assessment of the number of emboli; but undoubtedly 20 and 40 micron arterial filters remove many circulating emboli, although there are still particles and bubbles left in the perfusate. ${ }^{30}$

The number of microemboli detected in the perfusate may correlate poorly with the severity of the postoperative central nervous system dysfunction because of the diverse ability of different microemboli to obstruct the vascular bed of the brain. Reducing the quantity as much as possible, however, would seem reasonable.

In experimental and clinical studies arterial filtration prevented the formation of emboli, ${ }^{3034-36}$ improved the clinical outcome and neuropsychometric scores after operation, ${ }^{1618192225}$ reduced the incidence of emboli in neuropathological investigations, ${ }^{37-42}$ and prevented structural changes in the brain. ${ }^{126}$

There is some blood trauma with filters of small pore size, ${ }^{43}$ so the inclusion of a 40 micron filter has become popular. ${ }^{25} 394344$ Despite the use of microporous filters in the extracorporeal circulation unit, however, there are still many microaggregates and gaseous microemboli left in the perfusate. ${ }^{30}$ Arterial line filters do not replace the coronary suction filter, because if they serve as the only filter they will not be adequate. $^{30}$

It is impossible to define the safe filter pore size, but the experimental work by Prosenz $z^{45}$ showed that plastic microspheres smaller than 7 microns pass freely through the cerebral capillary bed, whereas those of 7-14 microns are sometimes trapped. Microspheres of 14-74 microns pass only if arteriovenous shunts have been opened in response to hypoxia. This and other experimental investigations suggest that the smallest filter pore size should be used. Our mea- surements of cerebral bloou how support but do not clinch this suggestion.

EFFECT OF ARTERIAL FILTRATION

On the basis of cerebral blood flow data corrected to a standard $\mathrm{PCO}_{2}$ of $40 \mathrm{~mm} \mathrm{Hg}(5.3 \mathrm{kPa}),{ }^{6}{ }^{10}$ arterial ${ }^{\bar{\rho}}$ filters significantly reduced the hyperaemia during the $\underset{\Omega}{\mathbb{\Phi}}$ rewarming procedure at $30^{\circ}, 33^{\circ}$, and $35^{\circ} \mathrm{C}($ fig $1 b)$ but did not completely prevent it. The significant re- duction in cerebral blood flow could be fortuitous. The same trend was, however, noted in the un- $\vec{\omega}$ corrected data (fig $1 a$ ) and cerebral blood flow doeso undoubtedly respond to changes in $\mathbf{P C O}_{2}$. Owing to $\vec{x}$ individual differences in the relationship between cerebral blood flow and $\mathrm{PCO}_{2}$, resulting change in cerebral blood flow may be $2-4 \%$ per $1 \mathrm{~mm} \mathrm{Hg}(0.13 \%$ $\mathrm{kPa}$ ) change in $\mathrm{PCO}_{2}$, but any correction will accen-ळ tuate the existing difference between the filter groupso and the control group (fig 1 and tables 2-4).

The significant reduction in cerebral blood flow occurred during the rewarming period, whereas no difference was noticed during the earlier cooling period. This could reflect differences in the amount of solid and gaseous particles constituting the population of emboli in the perfusate. The filters are moreo efficient at removing gaseous particles, which are known to increase during the rewarming procedure but our data are not conclusive.

The effect on cerebral blood flow induced by pro $\stackrel{\mathbb{\Omega}}{\circ}$ caine in the cardioplegic solutions also has to be con- $\overrightarrow{\overrightarrow{0}}$ sidered. The effect is transient, however, and is 3 noticed only during hypothermic bypass, just after? the infusion of the cardioplegic solution. ${ }^{8}$

Given that arterial filters of 20 or 40 microns slightly reduced cerebral blood flow but did not pre $\frac{0}{2}$ vent brain hyperaemia and filters of even smaller porex size would probably result in too much blood trauma, $\frac{5}{3}$ some other measure is needed to reduce cerebrak blood flow. Management of $\mathrm{PCO}_{2}$ could be a simple way of doing this, and hence appreciably reduce the amount of emboli which could be trapped in the brain capillaries. $^{12}$

\section{CARBON DIOXIDE TENSION}

Manipulation of $\mathrm{PCO}_{2}$ causes considerable changes in cerebral blood flow as hypercapnia produces vasodilation with increased flow and hypocapnia causes $\omega$ vasoconstriction with decreased flow (fig 5). The sen $\%$ sitivity to changes in $\mathrm{PCO}_{2}$ in our patients was withire the normal range. ${ }^{10}$ The considerable scatter in figure 5 was mostly due to variations in blood pressure; which has a known modulating effect on the relationship between cerebral blood flow and $\mathrm{PCO}_{2} \cdot{ }^{4}{ }_{\mathrm{D}}$ In this series of patients we added carbon dioxide to? the oxygenator. As carbon dioxide is a potent vaso $\triangle$ dilator, however, and consequently impairs the cere? 
bral autoregulation, we do not add it to the oxygenator any longer. In addition to the resulting beneficial effect on the cerebral autoregulation, a reduced $\mathrm{PCO}_{2}$ and hence a lower cerebral blood flow has the advantage that the number of circulating emobli entering the brain is considerably reduced.

\section{PERFUSION PRESSURE}

A reduced flow rate and arterial blood pressure ( $<60 \mathrm{~mm} \mathrm{Hg}$ ) during extracorporeal circulation have been advocated to prevent rewarming of the heart via a non-coronary collateral circulation, ${ }^{47}$ but they were associated with a high incidence $(75 \%)$ of the central nervous system dysfunction during the first week after operation. Other cardiac surgery centres regard cardiopulmonary bypass as a state of controlled shock and accept low arterial blood pressures. This policy, at least so far as the cerebral circulation is concerned, may entail a risk of brain damage.

Many papers incriminate hypotension as a major cause of dysfunction of the central nervous system. Witoszka et al $^{24}$ reported neurological abnormalities in patients with a low mean arterial blood pressure $(<45 \mathrm{~mm} \mathrm{Hg})$ during extracorporeal circulation. Javid et $\mathrm{al}^{21}$ reported neurological abnormalities in $60 \%$ if mean arterial blood pressure was lower than $50 \mathrm{~mm} \mathrm{Hg}$. Postmortem findings give additional support to the hypothesis that cerebral damage occurs at surgery and may be the result of inadequate cerebral perfusion. ${ }^{1524404849}$ The most common histological manifestation was the kind of neuronal degeneration attributed to anoxia. The lesions were distributed in arterial boundary zones and were similar to the experimental lesions that follow profound hypotension. ${ }^{4849}$ Boundary zone infarcts occur when there is oligaemic hypoxia due to episodes of reduced perfusion, the lesions being bilateral in nature.

The concept of autoregulation is well described and widely accepted. Our finding of the relationship between cerebral blood flow and mean arterial blood pressure during extracorporeal circulation supports the classical concept of autoregulation. The lower limit of autoregulation in our patients was reached at around $55-60 \mathrm{~mm} \mathrm{Hg}$ in mean arterial blood pressure, after which a further reduction in pressure reduced cerebral blood flow. Thus we cannot recommend a perfusion pressure lower than this if cerebral ischaemia is to be avoided.

\section{ISCHAEMIA}

The possibility of an ischaemic lesion as the underlying cause of dysfunction of the central nervous system after cardiac surgery is supported by the findings of intracellular markers in cerebrospinal fluid. ${ }^{1-3}$ The reactive brain hyperaemia noted in our patients supports this idea. The brain, however, either is more resistant to ischaemia than has previously been recognised or has sufficient compensatory potential to allow patients to regain full or near normal function weeks after extracorporeal circulation despite its severe early dysfunction.

Brain cells combine a high energy expenditure with a low energy reserve, and as they have only a modest capillarity an abundant supply of oxygen is needed to avoid brain ischaemia. Ischaemia may be global or regional, complete or partial. Conditions that reduce cerebral blood flow will lead to global incomplete ischaemia - for example, during hypotension or increased intracranial pressure. Regional complete ischaemia may result from embolism. In some tissues-for example, muscle-capillaries can be opened to meet the increased demands for blood flow. In brain tissue, however, no such recruitment is possible. If focal or global hypoxia is complicated by a reduced cerebral perfusion pressure the compensatory increase in cerebral blood flow is curtailed. As a result, the oxygen delivery is further compromised and the cellular energy state deteriorates.

Pronounced hypoxia can be tolerated without causing a reduction in the cerebral metabolic rate of oxygen or a major derangement in the cerebral energy state. Even arterial oxygen tensions of $20-25 \mathrm{~mm} \mathrm{Hg}$ $(2.7-3.3 \mathrm{kPa})$ can be tolerated if the mean arterial blood pressure is high enough to allow the reactive increase in cerebral blood flow that represents the main if not sole mechanism to prevent energy failure. Experimental manipulations that interfere with the compensatory increase in cerebral blood flow lead to energy failure at the cellular level. ${ }^{50}$

\section{CONCLUSION}

The abnormally high cerebral blood flow during hypothermia and the early rewarming period are probably the combination of an increased $\mathrm{PCO}_{2}$ and a diffuse microembolisation, the increase in cerebral blood flow being secondary to a prior hypoperfusion at the microcirculatory level. The formation of microemboli during cardiopulmonary bypass is unavoidable. Interposing arterial filters reduced but did not prevent the brain hyperperfusion during bypass. There are many good reasons for using arterial filters. Our data on cerebral blood flow constitute no proof, but along with other experimental and clinical studies they support the idea that arterial filtration should be used. The smaller the filter pore size the better. We would also emphasise the importance of maintaining an adequate cerebral perfusion pressure (> 55-60 mm Hg) to prevent regional or general cerebral ischaemia.

The study was supported by a grant from the Foundation of 1870, the Danish Heart Foundation, and 
the Danish Hospital Foundation for Medical Research (region of Copenhagen, Iceland, the Faroes, and Greenland).

\section{References}

1 Taylor KM, Devlin BJ, Mittra SM, Gillan JG, Brennan JJ, McKenna JM. Assessment of cerebral damage during open-heart surgery. A new experimental model. Scand J Thorac Cardiovasc Surg 1980;14:197-203.

2 Lundar T, Stokke O. Total creatine kinase activity in cerebrospinal fluid as an indicator of brain damage during open-heart surgery. Scand J Thorac Cardiovasc Surg 1983;17:157-61.

3 Aberg T, Ronquist G, Tydén H, Ahlund P, Bergström $K$. Release of adenylate kinase into cerebrospinal fluid during open-heart surgery and its relation to postoperative intellectual function. Lancet 1982;ii:1139-42.

4 Settergren G, Öhquist G, Lundberg S, Henze A, Björk VO, Persson B. Cerebral blood flow and cerebral metabolism in children following cardiac surgery with deep hypothermia and circulatory arrest. Clinical course and follow-up of psychomotor development. Scand J Thorac Cardiovasc Surg 1982;16:209-15.

5 Henriksen L. Cerebral blood flow following cardiac operations. Evidence suggestive of intraoperative microembolism. Lancet 1984; i:816-22.

6 Henriksen L, Hjelms E, Lindeburgh T. Cerebral blood flow measured in man by intraarterially injected ${ }^{133} \mathrm{Xe}$ : evidence suggestive of intraoperative microembolism. $J$ Thorac Cardiovasc Surg 1983;86:202-8.

7 Henriksen L, Hjelms E, Rygg IH, Skovsted P, Lindeburgh $\mathrm{T}$. Cerebral blood flow measured in patients during open heart surgery using intraarterially injected ${ }^{133}$ xenon. Journal of Cerebral Blood Flow Metabolism 1981;1:532-4.

8 Henriksen L, Barry DI, Rygg IH, Skovsted P. Cerebral blood flow during early cardiopulmonary bypass in man. Effect of procaine in cardioplegic solutions. Thoracic and Cardiovascular Surgeon (in press).

9 Høedt-Rasmussen KE, Sveinsdottir E, Lassen NA. Regional cerebral blood flow in man determined by intraarterial injection of radioactive inert gas. Circ Res 1966;18:237-47.

10 Olesen J, Paulson OB, Lassen NA. Regional cerebral blood flow in man determined by the initial slope of the intra-arterially injected ${ }^{133} \mathrm{Xe}$. Stroke 1971;2:519-40.

11 Siegel S. Nonparametric statistics for the behavioral sciences. New York: McGraw-Hill Compagny, 1956.

12 Elsass P, Henriksen L. Acute cerebral dysfunction after open-heart surgery. A reaction-time study. Scand $J$ Thorac Cardiovasc Surg 1984;18:161-5.

13 Fish KJ, Helms CB, Sarnquist FH, Tinklenberg J, Miller DC. Neuropsychological dysfunction after coronary artery surgery [abstract]. Anesthesiology 1982;57:A55.

14 Lee WH, Brady MP, Rowe JM, Miller WC. Effects of extracorporeal circulation upon behavior, personality, and brain function. Ann Surg 1971;173:1013-23.

15 Tufo HM, Ostfeld AM, Shekelle R. Central nervous system dysfunction following open-heart surgery. $J \boldsymbol{A} M \boldsymbol{A}$ 1970;212:1333-40.

16 Landis B, Baxter J, Patterson RH. Bender gestalt evaluation of brain dysfunction following open-heart surgery. $J$ Pers Assess 1974;38:556-62.
17 Branthwaite MA. Neurological damage related to openheart surgery. Thorax 1972;27:748-53.

18 Branthwaite MA. Detection of neurological damage during open-heart surgery. Thorax 1973;28:464-72.

19 Aberg T. Effect of open heart surgery on intellectual function. Scand J Thorac Cardiovasc Surg 1974;suppl흐 15:1-64.

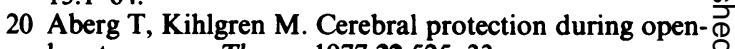
heart surgery. Thorax 1977;32:525-33.

21 Javid H, Tufo HM, Najaf H, Dye WS, Hunter JA, Ju- ٌ lian OC. Neurologic abnormalities following open-heart $\overrightarrow{0}$ surgery. J Thorac Cardiovasc Surg 1969;58:502-9.

22 Carlson RG, Landé AJ, Landis B, et al. The Lande- $\vec{\omega}$ Edwards membrane oxygenator during open heart surgery. J Thorac Cardiovasc Surg 1973;66:894-904.

23 Sotaniemi KA, Julasmaa A, Hokkanen ET. Neuro- $\times$ psychologic outcome after open-heart surgery. Arch $\stackrel{\oplus}{\rightarrow}$ Neurol 1981;38:2-8.

24 Witoszka MM, Tamura H, Indeglia R, Hopkins RW, Simeone FA. Electroencephalographic changes and cerebral complications in open-heart surgery. $J$ Thorac Car-o diovasc Surg 1973;66:855-64.

25 Willner AE, Caramante LL, Garvey JW, et al. The re- lationship between arterial filtration during open heart surgery and mental abstraction ability. Proceedings of the American Academy of Cardiovascular Performance $\overrightarrow{0}$ 1983;4:56-65.

26 Muraoka R, Yokota M, Aoshima M, et al. Subclinical changes in brain morphology following cardiac operations as reflected by computed tomographic scans of the brain. J Thorac Cardiovasc Surg 1981;81:364-9.

27 Gallagher EG, Pearson DT. Ultrasonic identification of sources of gaseous microemboli during open heart $\frac{\mathrm{Q}}{\mathrm{Q}}$ surgery. Thorax 1973;28:295-305.

28 Götze P, Huse-Kleinstoll G, Speidel H. Psychic and neu- $\overrightarrow{\vec{B}}$ rological dysfunction after open-heart surgery: a review of the present state of research. In: Speidel H, Rodewald $\mathrm{G}$, eds. Psychic and neurologic dysfunction after openheart surgery. Stuttgart: Georg Thieme Verlag, 1980:6-13.

29 Anonymous. Brain damage after open-heart surgery. Lancet 1982; i:1161-3.

30 Krebber HJ, Hill JD, Osborn JJ, Jatrides A. Micro- $\stackrel{x}{\sigma}$ emboli during extracorporeal circulation. Thoracic and Cardiovascular Surgeon 1980;28:249-52.

31 Kessler J, Patterson RH. The production of microemboli $\bigcirc$ by various blood oxygenators. Ann Thorac Surg 1970;9:221-8.

32 Solis RT, Wright CB, Gibs MB, Stevens PM. Quantitative studies of microaggregate formation in vivo ando in vitro. Chest 1974;65,suppl:44-7S.

33 Bethune DW. Organ damage after open-heart surgery. $N$ Lancet 1976;ii:1410-1.

34 Clark RE, Dietz DR, Miller JG. Continuous detection of $\bigcirc$ microemboli during cardiopulmonary bypass in animal N and man. Circulation 1976;54,suppl 3:74-8.

35 Patterson RH, Kessler J. Microemboli during cardiopulmonary bypass detected by ultrasound. Surg Gynecolo Obstet 1969;129:505-11.

36 Dutton RC, Edmunds LH, Hutchinson JC, Roe BB. Platelet aggregate emboli produced in patients during $\square$ cardiopulmonary bypass with membrane and bubble $\bar{D}$ oxygenators and blood filters. J Thorac Cardiovasc Surg 1974;67:258-65.

37 Hill JC, Aguilar MJ, Baranco A, Lanarolle P, Gerbode尺 F. Neurological manifestations of cardiac surgery. Ann 
Thorac Surg 1969;7:409-19.

38 Hill JD, Osborn JJ, Swank RL, Aguilar MJ, Gerbode F. Experience using a new dacron wool filter during extracorporeal circulation. Arch Surg 1970;101:649-52.

39 Osborn JJ, Swank RL, Hill JD, Aquilar MJ, Gerbode F. Clinical use of a Dacron wool filter during perfusion for open-heart surgery. J Thorac Cardiovasc Surg 1970; 60:575-81.

40 Aguilar MJ, Gerbode F, Hill JD. Neuropathologic complications of cardiac surgery. $J$ Thorac Cardiovasc Surg 1971;61:676-85.

41 Brennan R, Patterson RH, Kessler J. Cerebral blood flow and metabolism during cardiopulmonary bypass. Evidence of microembolic encephalopathy. Neurology 1971;21:665-72.

42 Patterson RH, Wasser JS, Porro RS. The effect of various filters on microembolic cerebrovascular blockade following cardiopulmonary bypass. Ann Thorac Surg 1974;17:464-73.

43 Guidoin R, Laperche Y, Martin L, Awad J. Disposable filters for microaggragate removal from extracorporeal circulation. J Thorac Cardiovasc Surg 1976;71:502-16.

44 Skagseth E, Frøysaker T, Refsum RB. Disposable filters for microemboli in cardiopulmonary bypass. $J$ Cardiovasc Surg 1974;15:318-22.

45 Prosenz P. Investigations on the filter capacity of the dog's brain. Arch Neurol 1971;26:479-88.

46 Henriksen L. Brain luxury perfusion during cardiopulmonary bypass in man. A study of the CBF response to changes in $\mathrm{CO}_{2}, \mathrm{O}_{2}$ and blood pressure. $\mathrm{J} \mathrm{Cereb} \mathrm{Blood}$ Flow Metabol (in press).

47 Ellis RJ, Wisniewski A, Potts R, Calhoun C, Loucks P, Wells MR. Reduction of flow rate and arterial pressure at moderate hypothermia does not result in cerebral dysfunction.. J Thorac Cardiovasc Surg 1980;79:173-80.

48 Brierley JB, Brown AN, Excell BJ, Meldrum BS. Brain damage in the rhesus monkey resulting from profound arterial hypotension. Nature, distribution and general physiological characteristics. Brain Res 1969;13:68-100.

49 Malone M, Prior P, Scholtz CL. Brain damage after cardiopulmonary by-pass: correlations between neuropsychological and neuropathological findings. $J$ Neurol Neurosurg Psychiatry 1981;44:924-31.

50 Carlsson C, Hägerdal M, Siesjö BK. Protective effect of hypothermia in cerebral oxygen deficiency caused by arterial hypoxia. Anesthesiology 1976;44:27-35. 